\title{
PLASMIDS IN MYCOPLASMA SPECIES ISOLATED FROM GOATS AND SHEEP AND THEIR PRELIMINARY TYPING ${ }^{\text {a }}$
}

\author{
Elmiro R. Nascimento ${ }^{{ }^{*}}$, Al J. DaMassa ${ }^{2}$, Richard Yamamoto $^{2}$, M. Graça F. Nascimento ${ }^{3}$ \\ ${ }^{1}$ Departamento de Patologia e Clínica Veterinária, Universidade Federal do Fluminense, Niterói, RJ, \\ Brasil. ${ }^{2}$ Department of Population Health and Reproduction, University of California, Davis, CA, \\ USA. ${ }^{3}$ CNP Agrobiologia, PSA/Universidade Federal Rural do Rio de Janeiro, Empresa \\ Brasileira de Agropecuária, Seropédica, RJ, Brasil.
}

Submitted: May 25, 1998; Returned to authors for corrections: August 17, 1998; Approved: November 12, 1998

\begin{abstract}
One-hundred-five (105) clinical isolates of mycoplasma from caprine origin and one isolate from ovine were surveyed for plasmids, which were present in thirty-three (31\%) of them. These mycoplasmas originated from 13 herds. Ten of them were symptomatic for mycoplasmal disease (mastitis, polyarthritis, septicemia) and three herds were asymptomatic, i.e., clinically normal. Twenty-eight isolates were Mycoplasma mycoides subspecies mycoides LC (large colony or caprine biotype), four were Mycoplasma capricolum subsp. capricolum and one was Mycoplasma cottewii. The isolated plasmids were linearized by $E c o$ RI, EcoRV, EcoRI and $E c o$ RV or BamHI and $E c o$ RV, and were of five sizes $(1.1,1.6,1.7,1.8$, and $1.9 \mathrm{Kbp})$. Based on restriction enzyme digestion and size of the linearized supercoiled extrachromosomal DNA, five plasmid types were recovered (p1II, p2III, p2V, p3I, and p4IV). The small size of these DNA elements probably exclude replicative forms of DNA virus, which are equal or larger than $8.0 \mathrm{Kbp}$.
\end{abstract}

Key words: Mycoplasma, plasmid, goat, endonuclease, electrophoresis

\section{INTRODUCTION}

Plasmids in Mycoplasma species (class Mollicutes) are unusual or rare, and only a few have been documented. Most extrachromosomal DNA isolated from mollicutes have been from viruses that are specific for mycoplasma, and the majority of the extrachromosomal DNA studies among these mycoplasma have been conducted on members of the genus Spiroplasma because of the availability of these nucleic acid elements in these organisms (15). Since the isolation of satellite DNA from Mycoplasma arthritidis (12) and M. hominis (19) few studies relating to the isolation of plasmids from members of the genus Mycoplasma have been reported. Since then, plasmids have been isolated from an unspeciated mycoplasma recovered from a baboon (13), and from a caprine strain of $M$. mycoides subsp. mycoides $(1,2,8)$. Thereafter, an unspeciated mycoplasma isolated from a goat was found to contain extrachromosomal DNA of probable plasmid origin (6).

Despite the presence of some reports concerning plasmid isolations from mycoplasma, the number of isolated plasmid types is small and there is little

\footnotetext{
* Corresponding author. Mailing address: Rua Elípse Baixa, 21, CEP 23890-000, Seropédica, RJ, Brasil. Fax (+5521) 610-6657. E-mail: mironascimento@hotmail.com

${ }^{a}$ Postdoctoral Research work of the first author under the orientation of R. Yamamoto and A.J. da Massa, University of Califórnia, Davis, USA.
} 
information on the function of these DNA elements as compared to bacteria. Additionally, information on transcriptional differences, between bacteria plasmid and the mycoplasma system (14) has incited more research in this area.

In the present study, we report on the occurrence of plasmids in 106 caprine or ovine mycoplasmal isolates (105 caprine, 1 ovine) recovered from 10 diseased and three asymptomatic herds, i. e., clinically normal goats.

\section{MATERIALS AND METHODS}

Mycoplasma strains used: One-hundred-five caprine and one ovine (isolate GM630A, Table 1) mycoplasma isolates were examined. The isolates belonged do Dr. Al J. DaMassa Collection, Department of Population Health and Reproduction, University of California, Davis, USA, and only those with retrievable informations were used. They originated from separate farms and included mycoplasma from three asymptomatic and 10 symptomatic herds showing mastitis, polyarthritis, or septicemia either singly or in combination (Table 1). M. cottewii, type strain VIS, (7), was obtained from G. S. Cottew, CSIRO, Division of Animal Health, Parkville, Victoria, Australia. With the exception of M. cottewii, and isolates from herds "C", GM261B and GM267C, recovered from the external ear canal, and GM1015A (Table 1), all other mycoplasma under study originated from caprine (nine herds) or ovine (one herd) located in the Central Valley of California, USA, which had been involved in outbreaks of mycoplasmosis as reported previously $(4,5,6,9)$. Additionally, M. mycoides subsp. mycoides strain GM12 (4) was used as a positive control because it contains a plasmid of about $1.85 \mathrm{Kbp}(8)$. Prior to identification each mycoplasma isolate was filtercloned a minimum of two times through $300 \mathrm{~nm}$ filters according to a procedure described elsewhere (18). For purposes of this study, the term M. mycoides subsp. mycoides will refer only to "large colony or caprine biotypes" and not to bovine or "small colony" forms of the organism.

Mycoplasma strains and identification: Mycoplasmas were identified by a growth-inhibition procedure (3) modified by the use of agar wells rather than discs.

Growth media, culturing, and processing: All isolates were grown for 24 to 48 hours in $50 \mathrm{ml}$ of modified Hayflick liquid medium "B" described elsewhere (10). The cultures were centrifuged for 15 minutes at 20,000 x G. The cells pellets were washed twice in PBS, pH 7.4, resuspended in $5 \mathrm{ml}$ of PBS and stored in $1 \mathrm{ml}$ aliquots at $-20^{\circ} \mathrm{C}$ for subsequent use.

DNA extraction and digestion: The DNA was extracted from mycoplasma cells by an alkaline lysis mini-preparation procedure (17). Aliquots of the sedimented DNA from each extraction were electrophoresed in agarose gel, stained with ethidium bromide, visualized under ultraviolet light, and photographed as previously described (16). Aliquots from samples containing supercoiled extrachromosomal DNA were digested with BamHI, EcoRI, and EcoRV according to a standard protocol (17) for linearization and size determination (16), for preliminary typing. Following digestion, samples from each reaction were electrophoresed, visualized, and photographed as described above.

Virus assay: The supernatant of five plasmidpositive mycoplasma strains (GM30A, GM261B, GM1013, GM1043, GM630A) were assayed for virus by a standard method (19), and also by a plaque assay method described elsewhere (11).

\section{RESULTS}

Mycoplasma strains: The mycoplasma examined in this study were identified either as $M$. capricolum subsp. capricolum, M. mycoides subsp. mycoides LC (large colony or caprine biotype), or as $M$. cottewii.

Data pertaining to the identity of the Mycoplasma, the animal species from which it was isolated, the plasmid types that were recovered, and the clinical signs caused by the mycoplasma in the herd in question are presented in Table 1. Of the 106 mycoplasma isolates examined, 31.1\% (33/106) contained plasmids. The plasmid-positive isolates were recovered from 13 different herds; 12 from California, USA, and one from Australia. Of the 13 plasmid-positive herds, 10 were symptomatic for mycoplasmal disease (mastitis, polyarthritis, septicemia, singly or in combination), and 3 were asymptomatic; one of the symptomatic herd was of sheep origin (Table 1). Of the 33 plasmid-positive isolates, $85.0 \%(28 / 33)$ were derived from $M$. mycoides subsp. mycoides, $12.0 \%$ (4/33) from $M$. capricolum subsp. capricolum, and $3.0 \%(1 / 33)$ from M. cottewii. 
Table 1. Characteristics of the mycoplasma isolates and their recovered plasmid types

\begin{tabular}{|c|c|c|c|c|c|c|}
\hline Herd & $\begin{array}{c}\text { Mycoplasma } \\
\text { Species }\end{array}$ & $\begin{array}{c}\text { Disease } \\
\text { signs }\end{array}$ & $\begin{array}{c}\text { Isolate-total/ } \\
\text { herd }\end{array}$ & $\begin{array}{c}\text { Plasmid size } \\
(\mathrm{Kbp})\end{array}$ & $\begin{array}{l}\text { Digestion } \\
\text { assay }\end{array}$ & $\begin{array}{c}\text { Plasmid } \\
\text { types }\end{array}$ \\
\hline A & $\mathrm{Mmm}$ & $\mathrm{P}$ & 1 & 1.8 & EcoRI & p1II \\
\hline B & $\mathrm{Mmm}$ & M, P, S & 18 & 1.8 & EcoRI & p1II \\
\hline \multirow[t]{2}{*}{$\mathrm{C}$} & $\mathrm{Mmm}$ & None $^{a}$ & 1 & 1.8 & & p1II \\
\hline & Mcc & None & 2 & 1.1 & EcoRV & $\begin{array}{l}\text { EcoRI } \\
\text { p2V }\end{array}$ \\
\hline D & $\mathrm{Mmm}$ & $\mathrm{P}$ & 1 & 1.8 & EcoRI & p1II \\
\hline E & $\mathrm{Mmm}$ & $\mathrm{P}$ & 1 & 1.8 & EcoRI & p1II \\
\hline $\mathrm{F}$ & $\mathrm{Mmm}$ & $\mathrm{P}$ & 1 & 1.7 & EcoRV & p2III \\
\hline G & $\mathrm{Mmm}$ & $\mathrm{P}$ & 1 & 1.9 & $E c o$ RI/V & p3I \\
\hline $\mathrm{H}$ & $\mathrm{Mmm}$ & $\mathrm{P}$ & 2 & 1.8 & EcoRI & p1II \\
\hline I & $\mathrm{Mmm}$ & $\mathrm{P}$ & 1 & 1.8 & EcoRI & p1II \\
\hline $\mathrm{J}$ & $\mathrm{Mmm}$ & M & 1 & 1.7 & EcoRV & p2III \\
\hline K & $\mathrm{Mcc}^{\mathrm{b}}$ & $\mathrm{P}$ & 1 & 1.1 & EcoRV & $\mathrm{p} 2 \mathrm{~V}$ \\
\hline $\mathrm{L}$ & Mcc & None & 1 & 1.8 & EcoRI & p1II \\
\hline M & Mci & None $^{\mathrm{a}}$ & 1 & 1.6 & $\mathrm{Bam} / \mathrm{Eco}$ & p4IV \\
\hline
\end{tabular}

$\mathrm{Mmm}=$ Mycoplasma mycoides subsp. mycoides, $M=$ mastitis, $\mathrm{P}=$ polyarthritis, $\mathrm{S}=$ septicemia, $\mathrm{a}=$ mycoplasma recovered from the external ear canal, Mcc = Mycoplasma capricolum subsp. capricolum, $\mathrm{b}=$ isolate GM630A from sheep, EcoRI $/ \mathrm{V}=E c o \mathrm{RI}$ and EcoRV, Mci $=$ Mycoplasma cottewii, and Bam/Eco = Bam HI and EcoRV.

Mycoplasma virus and plasmids: Virus was not recovered from culture supernatant or by the plaque assay procedure from the five mycolasma isolates that were studied. The results and/or characteristics pertaining to the recovered plasmids are shown in Table 1, Fig. 1 and Fig. 2. Based on restriction enzyme digestion, the plasmids were arbitrarily assigned to groups 1 to 4 depending on whether they were linearized, respectively, by $E c o$ RI, by $E c o$ RV, by $E c o$ RI and EcoRV, or by BamHI and EcoRV, (Fig. 1). They were further assigned to subgroups I to $\mathrm{V}$ according to their approximate size (Kbp) of 1.9 (one digested by EcoRI and EcoRV), 1.8 (all digested by EcoRI), 1.7 (two digested by EcoRV), 1.6 (one digested by $B a m \mathrm{HI}$ and $E c o \mathrm{RV}$ ) and, 1.1 (three digested by EcoRV) (Table 1, and Fig.1), respectively. By combining the enzyme digestion reaction and the size of the linearized form, five different types of plasmid were found, namely p1II in 25 isolates of $M$. mycoides subsp. mycoides and in one isolate of $M$. capricolum subsp. capricolum; p2III found in two isolates of $M$. mycoides subsp. mycoides; $\mathrm{p} 2 \mathrm{~V}$ found in three isolates of M. capricolum subsp. capricolum; $\mathrm{p} 3 \mathrm{I}$ found in one isolate of M. mycoides subsp. mycoides and p4IV found in M. cottewii strain GM612 (Table 1). Only one plasmid type was detected in any single isolate, but a particular mycoplasma species was found to carry more than a single plasmid type. For example, different isolates of $M$. mycoides subsp. mycoides carried plasmid types p1II, p2III and p3I (Table 1). All the $18 \mathrm{M}$. mycoides subsp. mycoides strains from herd $B$, which were recovered during one outbreak of mastitis and polyarthritis, contained the same type of plasmid (Table 1, and Fig. 2).

\section{DISCUSSION}

Although all the plasmid-positive mycoplasma isolates were not routinely assayed for the presence of virus, the sizes of the recovered extrachromosomal DNAs were were small enough (1.1 to $1.9 \mathrm{Kbp})$ to exclude replicative forms (RF) of viral DNA. The size of the reported RF DNAs from mollicutes is equal to or over than $8.0 \mathrm{Kbp}(15)$.

The rate of occurrence of plasmids among the field strains of caprine mycoplasmas in this study was relatively high, in contrast with a previously reported plasmid survey on mycoplasmas from various animal hosts (13). In the United States, severe large-scale outbreaks of caprine mycoplasmosis are on record $(4,5,6,9)$, particularly from California, which was the origin of all except one of the isolates used in this study. The extensive use of antimicrobial drugs in 


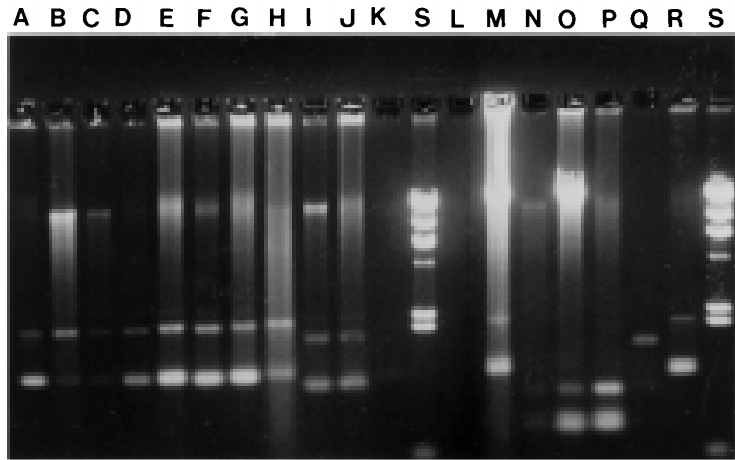

A B C D E F G H I J K S L M NO P Q R S

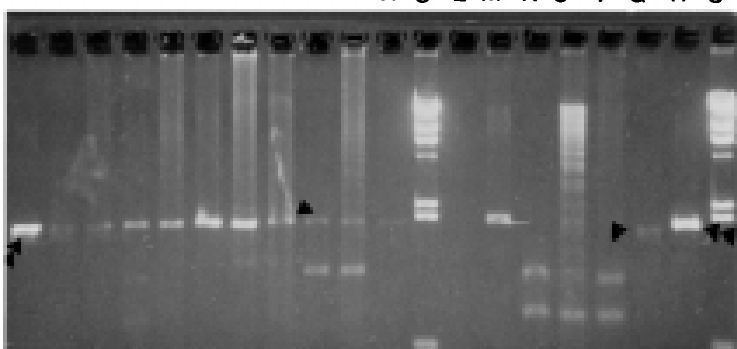

A B C DEFGHIJK SLMN OPQR

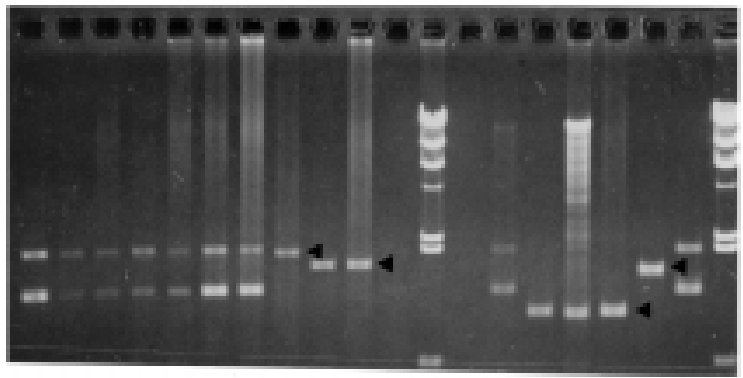

Figure 1. Agarose gel electrophoresis of plasmids from mycoplasmas recovered from 16 mycoplasma isolates under study. Top figure represents supercoiled (uncut) plasmids. Middle, represents EcoRI digested plasmids. Bottom, represents $E c o$ RV digested plasmids. A and $\mathrm{R}=$ plasmid from $\mathrm{GM} 12$ (control), $\mathrm{B}=\mathrm{GM} 1031 \mathrm{~B}, \mathrm{C}=\mathrm{GM} 1031 \mathrm{G}$, $\mathrm{D}=\mathrm{GM} 728 \mathrm{~A}, \mathrm{E}=\mathrm{GM} 975, \mathrm{~F}=\mathrm{GM} 262 \mathrm{E}, \mathrm{G}=\mathrm{GM} 3, \mathrm{H}=\mathrm{GM} 1019, \mathrm{I}=$ GM1013, $\mathrm{J}=\mathrm{GM} 1053, \mathrm{~K}=\mathrm{GM} 1043, \mathrm{~L}=$ blank, $\mathrm{M}=\mathrm{GM} 1015 \mathrm{~A}, \mathrm{~N}=$ GM630A, O = GM267C, P = GM261B, and Q = GM612. Lanes $\mathrm{S}$ represent molecular-weight standard (HindIII-cleaved lambda phage DNA). Single-arrows indicate the size in base pair of the linearized plasmids. Double-arrows indicate the size $(1.85 \mathrm{Kbp})$ of the linearized pKMK1 plasmid recovered from M. mycoides subsp. mycoides strain GM12 (Dybvig and Khaled, 1990).

these herds may have contributed to the high occurrence of plasmid in the mycoplasma strains isolated in this study. Most of the plasmids were recovered from $M$. mycoides subsp. mycoides isolates, but $M$. capricolum subsp. capricolum and $M$. cottewii were also found to contain plasmids. Excluding one plasmid from a single symptomatic sheep herd studied, most of them (26/33) originated
A B C D E F G H I J K L M N O P Q R S T
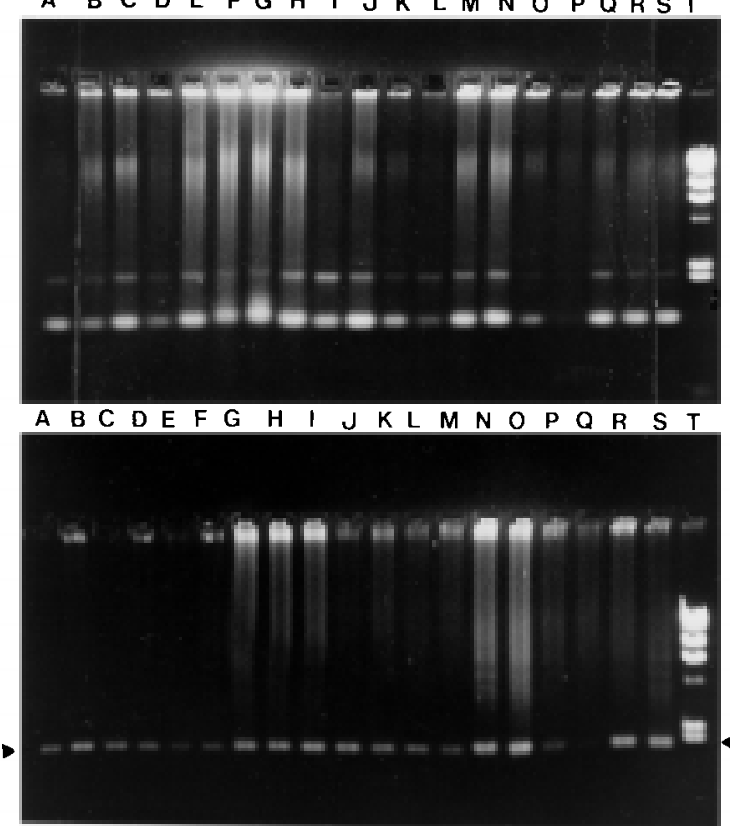

Figure 2. Agarose gel electrophoresis of plasmids from mycoplasmas recovered from all mycoplasma isolates of herd B. Top figure represents supercoiled (uncut) plasmids. Bottom, represents EcoRI digested plasmids. $\mathrm{A}=$ plasmid from $\mathrm{GM} 12$ (1.85 Kbp, control), $\mathrm{B}=$ $\mathrm{GM} 32 \mathrm{G}, \mathrm{C}=\mathrm{GM} 32 \mathrm{D}, \mathrm{D}=\mathrm{GM} 28 \mathrm{~F}, \mathrm{E}=\mathrm{GM} 32 \mathrm{~B}, \mathrm{~F}=\mathrm{GM} 32 \mathrm{H}, \mathrm{G}=$ GM32A, $\mathrm{H}=\mathrm{GM} 28 \mathrm{H}, \mathrm{I}=\mathrm{GM} 32 \mathrm{C}, \mathrm{J}=\mathrm{GM} 32 \mathrm{E}, \mathrm{K}=\mathrm{GM} 28 \mathrm{D}, \mathrm{L}=$ GM30A, M = GM32J, N = GM28G, O = GM30B, P = GM32K, Q = GM30G, $\mathrm{R}=\mathrm{GM} 30 \mathrm{~L}$, and $\mathrm{S}=\mathrm{GM} 28 \mathrm{C}$. Lane T represents molecularweight standard (HindIII-cleaved lambda phage DNA). The arrows indicate the migration size in Kbp of the linearized plasmids.

from mycoplasma isolates from disease outbreaks in caprines. Plasmids of different types were found in different isolates of both $M$. mycoides subsp. mycoides and M. capricolum subsp. capricolum.

Based on size and herd of origin the p1II plasmid is probably of the same type as the pKMK1 described previously (8). Plasmids of about $1.7 \mathrm{Kbp}$ have been reported previously (1), but there seems to exist no previous report of a mycoplasma plasmid as small as $1.1 \mathrm{Kbp}$. The finding of new types of plasmids, more importantly the smaller ones, because they can easily be sequenced and engineered, may add to gene expression studies in mycoplasmas as bacterial plasmids are not fully compatible with the transcription system of the former organism as evidenced previously (14). It is hoped that some of the findings reported in this study will add further to the understanding of the role of plasmids within mycoplasma cells, as well as in mycoplasma infection. 


\section{RESUMO}

\section{Plasmídios em espécies de Mycoplasma isoladas de caprinos e de ovinos e sua tipagem preliminar}

Um total de 105 amostras clínicas de micoplasma, originárias de caprinos, e uma de ovino foram investigadas quanto a presença de plasmídios, que foram observados em trinta e três (31\%) delas. Esses micoplasmas provieram de 13 rebanhos. Dez desses rebanhos eram sintomáticos para micoplasmose (mastite, poliartrite, septicemia) e três eram assintomáticos, i.é., clinicamente sadios. Vinte e oito amostras eram Mycoplasma mycoides subespécie mycoides LC ("large colony" ou biotipo caprino), quatro eram M. capricolum subsp. capricolum e uma era M. cottewii. Os plasmídios foram linearizados com endonucleases EcoRI, EcoRV, EcoRI e EcoRV ou $B a m \mathrm{HI}$ e $E c o \mathrm{RV}$ e apresentaram cinco tamanhos (1,1; 1,$6 ; 1,7 ; 1,8$ e 1,9 Kbp). Com base na digestão pela enzima de restrição e o tamanho dos DNA extracromossomais, cinco tipos de plasmídio foram encontrados (p1II, p2III, p2V, p3I e p4IV). O reduzido tamanho desses DNA circulares muito provavelmente exclui formas replicativas de vírus DNA, cujo tamanho é igual ou maior que $8,0 \mathrm{Kbp}$.

Palavras-chave: Mycoplasma, plasmídio, caprino, endonuclease, eletroforese

\section{REFERENCES}

1. Bergemann, A.D.; Finch, L.R. Isolation and restriction endonuclease analysis of a mycoplasma plasmid. Plasmid, 19:6870, 1988 .

2. Bergemann, A.D.; Whitely, J.C.; Finch, L.R. Homology of mycoplasma plasmid pADB201 and staphylococcal plasmid pE194.J. Bacteriol. 171:593-595, 1989.

3. Black, F.T. Modification of the growth inhibition test and its application to human T-mycoplasmas. Appl. Microbiol. 25:528$533,1973$.
4. DaMassa, A.J.; Brooks, D.L.; Adler, H.E. Caprine mycoplasmosis: widespread infection in goats with Mycoplasma mycoides subsp. mycoides (large colony type). Amer. J. Vet. Res. 44:322-325, 1983.

5. DaMassa, A.J.; Brooks, D.L.; Holmberg, C. A.; Moe, A.I. Caprine mycoplasmosis: an outbreak of mastitis and arthritis requiring the destruction of 700 goats. Vet. Rec. 120:409-413,1987.

6. DaMassa, A.J.; Nascimento, E.R.; Khan, M.I., Yamamoto, R.; Brooks, D.L. Characteristics of an unusual mycoplasma isolated from a case of caprine mastitis and arthritis with possible systemic manifestations. J. Vet. Diagn. Invest. 3:55-59, 1991.

7. DaMassa, A.J.; Tully, J.G.; Rose, D.L.; Pitcher, D.; Leach, R.H.; Cottew, G.S. Mycoplasma auris, sp. nov., M. cottewii sp. nov., and $M$. yeatsii sp. nov., new sterol-requiring mollicutes from the external ear canal of goats. Int. J. Syst. Bacteriol. 44:479-484, 1994.

8. Dybvig, K.; Khaled, M. Isolation of a second cryptic plasmid from Mycoplasma mycoides subsp. mycoides. Plasmid. 24:153$155,1990$.

9. East, N.E.; DaMassa, A.J.; Logan, L.L.; Brooks, D.L.; McGowan, B. Milkborne outbreak of Mycoplasma mycoides subsp. Mycoides infection in a commercial goat dairy. J. Amer. Vet. Med. Assoc. 182:1338-1341, 1983

10. Freundt, E.A. Culture media for classic mycoplasmas. In: Razin, S; Tully, J.G. (eds.). Methods in Mycoplasmology, Vol. I. Academic Press, Inc., San Francisco, California, USA. 1983, p. 127-135.

11. Gourlay, R.N. Isolation and characterization of mycoplasma viruses. In: Razin, S; Tully, J.G. (eds.). Methods in Mycoplasmology, Vol. II. Academic Press, Inc., San Francisco, California, USA. 1983, p. 413-420.

12. Haller, R. N., and Lynn E. J. Satellite DNA's in Mycoplasma arthritidis and a stable bacterial L form. In: Bacteriol. Proc., American Society for Microbiology, Washington, DC, 968, p. 68.

13. Harasawa, R.; Barile, M.F. Survey of plasmids in various Mycoplasmas. Yale J. Biol. and Med. 56:783-788, 1983.

14. Marais, A.; Bové, J.M.; Dallo, S.F.; Baseman J.B.; Renaudin, J. Renaudin.Expression in Spiroplasma citri of an epitope carried on the G fragment of the cytadhesin P1 gene from Mycoplasma pneumoniae. J. Bacteriol 175:2783-2787, 1993.

15. Razin, S. Molecular biology and genetics of mycoplasmas (Mollicutes). Microbiol. Rev. 49:419-455,1985.

16. Rodriguez, R.L.; Tait, R.C. Recombinant DNA techniques: an introduction. The Benjamin/Cummings Publishing Company, Inc., Menlo Park, CA, USA, 1983, p. 67-79.

17. Sambrook, J.; Fritsch, E.F.; Maniatis, T. Molecular cloning: $a$ laboratory manual. Vol. I, Cold Spring Harbor Laboratory Press, Cold Spring Harbor, New York, USA, 1989, p.1.3-1.110.

18. Tully, J.G. Cloning and filtration techniques for mycoplasmas. In: Razin, S.; Tully, J.G., (eds). Methods in Mycoplasmology, Vol. I. Academic Press, Inc., San Francisco, California, USA. 1983, p.173-177.

19. Zouzias, D.; Mazaitis, A.J.; Simbercoff. Extrachromosomal DNA of Mycoplasma hominis. Biochem. Biophys. Acta.312:484-491, 1973. 